\title{
Elementary apomictic processes in Rubus L.
}

\author{
ROMANA CZAPIK
}

Institute of Botany, Department of Plant Cytology and Embryology, Jagiellonian University, ul. Grodzka 52, 31-044 Kraków, Poland

Abstract

Two elementary apomictic processe were found in the examined Rubus species: $R$. saxatilis developed diplosporous and aposporous embryo sacs, $R$. cresius - displosporous, apart from meiotic ones. These results confirmed the wide occurrence of facultative apomixis and intraspecific differentiation of the mode of reproduction within the taxa of the investigated genus.

Embryological and genetic investigations revealed a complicated system of reproduction in the genus Rubus L. Normal sexual processes, facultative apomixis and autogamy may be found here within the same species. Some subgenera: Idaeobatus, Cyclactis and Chamaemorus were believed to be composed of sexual members (H es lop-Harrison, 1953). However, intraspecific variation of reproduction is to be expected in a genus where facultative apomixis occurs. A good example is $R$. idaeus from the subgenus Idaeobatus. Its diploid representatives were amphimictic ( $\mathrm{Chr}$ isten, 1952) but the results of experimental crosses of diploids suggested the occurrence of unreduced egg cells and parthenogenesis (A a lders, 1964). Also triploid forms of this species were facultatively apomictic (Petrov, 1939; Pratt et al., 1958; Petrov et al., 1974; P etrov, Sukhareva, 1977).

Embryological observations showed that meiotic, reduced embryo sacs and apomeiotic, unreduced ones could be formed in Rubus. The apomeiotic embryo sacs are more often of diplosporous and seldom of aposporous origin. Both apomictic tendencies seem to be separated, but in a few cases the simultanous development of diplosporous and aposporous initial cells has been described. They were found in the same individual and even in the same ovule ( $\mathrm{Chr}$ isten, 1950). Thus, in the apomictic representatives of Rubus, a meiotic tendency was stated which might occur together with elementary apomictic processes: diplospory, diplospory and apospory or apospory. 
The development of seeds in Rubus is connected with pseudogamy; fertilization of the central cell is necessary for endosperm formation. The embryo may develop in meiotic or apomeiotic embryo sacs after fertilization of egg cells or without fertilization. The available embryological data gave evidence of parthenogenesis only, while no case of apogamy was recorded.

The present results refer to the tetraploid plants $(2 \mathrm{n}=28)$ belonging to two species: $R$. saxatilis $\mathrm{L}$. and $R$. caesius $\mathrm{L}$. The former, a member of the subgenus Cyclactis, which was believed to be composed of sexual plants, had not been examined previously ( $\mathrm{C} \mathrm{z} \mathrm{a} \mathrm{p} \mathrm{i} \mathrm{k,} \mathrm{1980).} \mathrm{In} \mathrm{the} \mathrm{latter}$ sexual and apomictic reproductive forms were described (Lidforss, 1914; C hristen, 1950; D ow rick, 1961; Gerlach, 1965). The material was fixed in natural habitats. The transplanted specimens of $R$. saxatilis were pollinated in controlled conditions of the experimental field.

The embryological observations and the results of intraspecific pollinations did not reveal a complete apomictic cycle in individuals of $R$. saxatilis from three localities in southern and northern Poland (Młynicka Valley in Ojców National Park, Olsztyn-Likusy and Augustów-Lipowiec). Parthenogenetic development of egg cells could not be stated but apomeiotic initial cells and young unreduced embryo sacs occurred in some ovules which as a rule contained meiotic stages (Figs 1-4).

Apomeiotic embryo sacs seemed to occur more often in the upper degenerating ovules of the two-ovular ovary. One to three tetrads developed in the lower, functional ovule, one tetrad in the upper one. Single initial cells were visible at the meiotic stage. They were mostly diplosporous, only some of them - aposporous. These two apomictic tendencies were not observed in the same ovule.

It is unknown whether the unreduced embryo sacs were functional in $R$. saxatilis. Mature ovules contained single embryo sacs the ploidy level of which could not be verified. Embryos did not develop in emasculated and isolated flowers. In addition, in agreement with self-incompatibility of these plants, no signs of fertilization could be found after self- or clonal pollinations. In old unfertilized embryo sacs secondary nuclei were visible. This seems to be a rare picture in Rubus, where fusion of polar nuclei coincides with their fertilization. Seeds were obtained after experimental pollinations between plants from various populations.

In $R$. caesius both sexual reproduction and apomixis were recorded. The plants from England, Finland and Poland contained meiotic embryo sacs and were sexual (Dowrick, 1961). Swiss material was facultatively apomictic ( $\mathrm{Chr}$ isten, 1950). The plants developed meiotic, diplosporous and in single cases also aposporous embryo sacs. It should 

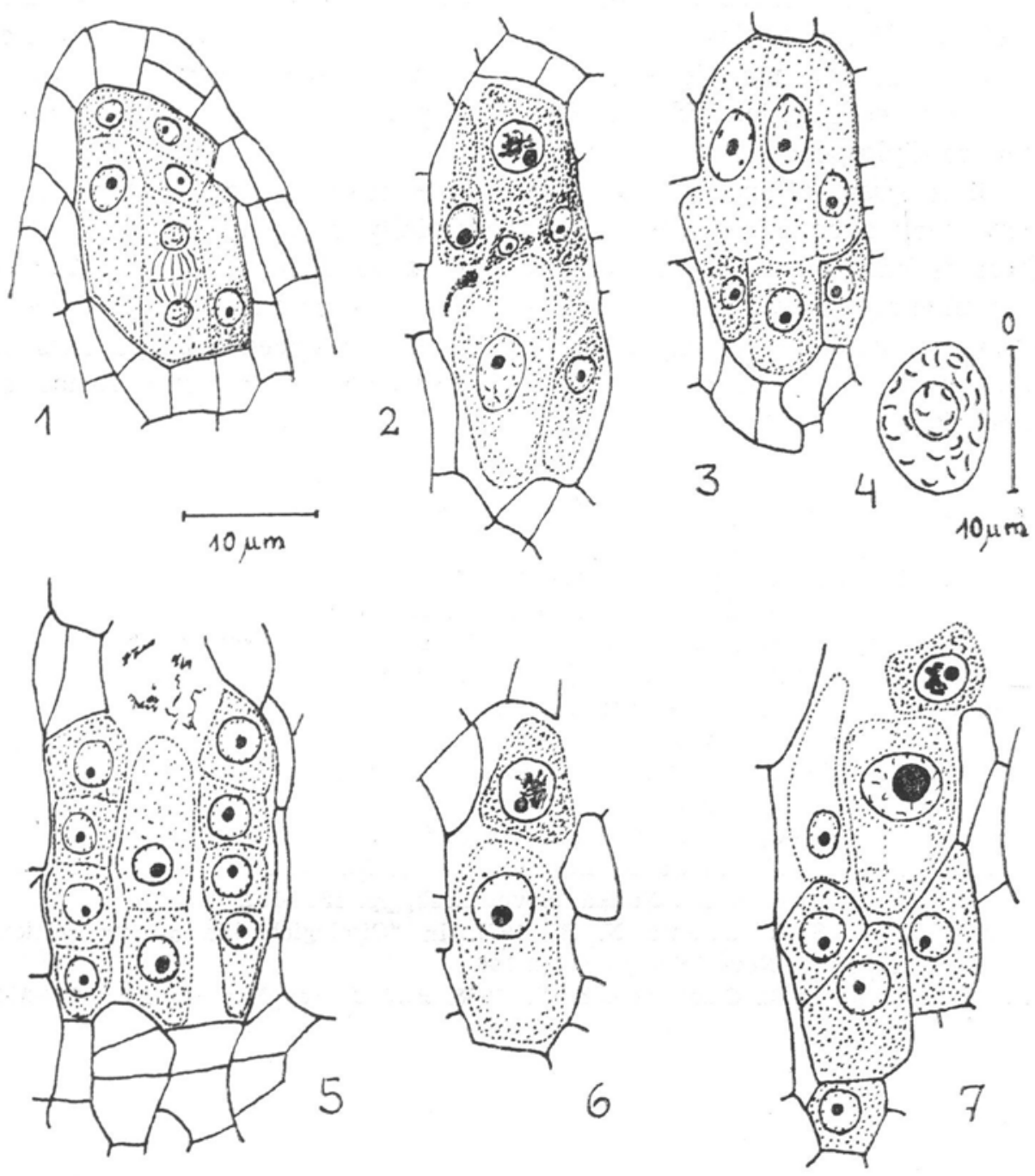

Figs 1-7. Young developmental stages in ovules of $R$. saxatilis (1-4) and $R$. caesius (5-7)

1 - telophase I; 2 - diplosporous and 3 - aposporous initial cell; 4 - prophase in unreduced embryo sac; 5 - tetrads; 6 and 7 - diplosporous initial cells.

be added that the cases of autogamy were described in $R$. caesius by G e r l a c h (1965).

The present material included four specimens from southern Poland: Pieprzowe Hills near Sandomierz, Biała Góra near Sanok, Bystra Podhalańska and Saboniowice near Kraków.

The results were similar to those of $\mathrm{Chr}$ isten (1950). There was no amphimictic plant among the investigated specimens. In all samples 
tetrads or diplosporous embryo sacs occurred in degenerating upper and functional lower ovules (Figs 5-7). Unreduced uninucleate embryo sacs appeared at the meiotic stage of the ovule together with enlarged archespore cells which did not divide. No plant was entirely meiotic and no pure diplosporous specimen was found.

These observations give more evidence to the wide occurrence of elementary apomictic processes and especially of apomeiosis in Rubus. There is only the question of the type of conditions which influence their phenotypic manifestation. It is also highly probable that the realization of the complete apomictic cycle in unreduced embryo sacs of $R$. saxatilis could be possible as it was observed in some forms of R. caesius.

\section{REFERENCES}

A a 1 d e r S L. E., 1964. Nature 204: 101-102.

Christen H. R., 1950. Ber. Schweiz. Bot. Ges. 60: 153-198.

$\mathrm{Christen} \mathrm{H.} \mathrm{R.,} \mathrm{1952.} \mathrm{Z.} \mathrm{ind.} \mathrm{Abstamm.-Vererbungslehre} \mathrm{84:} \mathrm{454-461.}$

C z a pik R., 1980. Acta Biol. Cracov. ser. Bot. (in press).

Dowrick G. J., 1961. Nature 191: 680-682.

Gerla ch D., 1965. Biol. Zbl. 84: 611-633.

Heslop-H a rris on G., 1953. New Phytol. 52: 22-39.

Lidfors s B., 1914. Ztschr. Vererb. 12: 1-13.

Petrov D. F., 1939. Compt. Rend. Acad. Sc. URSS 22: 353-355.

Petrov D. F., Sukhareva N. B., Liznev V. N., 1974. In "Apomikticheskoe razmnozhenie i geterozis". Nauka, Novosibirsk, pp. 184-192.

Petrov D. F., Sakhareva N. B., 1977. In "Citologicheskie osnovy selekcii rastenij". Nauka, Novosibirsk, pp. 142-146.

Pratt C., Einset J., Clausen R. T., 1958. Bull Torrey Bot. Club 85: 242-254. 